\title{
Urbanization and risks: case of Bejaia city in Algeria
}

\author{
Walid Hamma ${ }^{a}$, Alexandru-Ionuţ Petrişor ${ }^{* b}$ \\ a Abu Backr Belkaid University of Tlemcen, Algeria \\ b 'Ion Mincu' University of Architecture and Urban Planning, Romania
}

Urbanization is a worldwide process, occurring rapidly with adverse consequences on the environment and people. More exactly, urbanization aggravates natural risks and creates additional artificial risks; this is a key issue for urban planning, which can reduce the exposure and negative outcomes if its provisions are properly enforced. This article is based on observations from Bejaia, Algeria. Each year, the city suffers from disasters including floods, forest fires and landslides. This situation has led to the question whether urban planning observes the regulations from other domains. In order to answer it, different risks threatening the city were modeled and mapped. The results consist of computing the number of buildings situated within non-aedificandi zones by the type of risk. The results show that 15,832 buildings violate the law. Moreover, natural hazards $(78.31 \%)$ are a more important threat than the artificial ones (21.69\%). The most important natural risks are due to forest fires (44.82\%), and the explosion of the industrial zones (15.24\%) is the dominant artificial risk. The findings show that planning can help reducing the risk exposure within the urban areas, if the planning provisions are properly enforced. Moreover, the article makes a significant contribution to demonstrating the possible consequences of sacrificing long-term safety for short-term political interests.

Key Words: Planning, regulation, hazards, safety, prevention, enforcement.

Article Info: Received: March 12, 2017; Revised: May 5, 2018; Accepted: May 10, 2018; Online: May 25, 2018.

\section{Introduction}

The analysis of dangerous phenomena determined a specific terminology; it becomes a risk when the event, also called hazards, exceeds some thresholds and produces casualties or economic losses (Grecu, 2008; Boştenaru Dan et al.,

* Corresponding author

Address: "Ion Mincu" University of Architecture and Urban Planning, str. Academiei 1820, sector 1, 010014, Bucharest, Romania

Phone: +4.021.307.7191 | Email: alexandru_petrisor@yahoo.com

(C)2018 Human Geographies; The authors

(c) (7) This work is licensed under a

Creative Commons Attribution 4.0 International License. DOI:10.5719/hgeo.2018.121.6 
2014). Hazards, classified as urban or anthropogenic, are often synonymous with the dangerous phenomena, and usually imply the pre-existence of risks (Cheval, 2015). Risks are internal, mental models, with a strong societal influenced, used by people for coping with the dangerous phenomena under a certain level of psycho-social vulnerability (Armaş et al., 2017), and can be seen as the product of hazard, exposure, and vulnerability (Knoop et al., 2014). A vulnerability is a predisposition for risk (Boştenaru Dan et al., 2014) or the ability to anticipate, coping with, and recovering after the impact of hazards (Cheval, 2015). Nevertheless, urban planners consider that hazards are contextual, while vulnerability and risk are features shaping the urban system, and distinguish (a) natural, (b) anthropogenic, and (c) structural risks (Florescu, 2009). In this article, the term risk will be used consistently, in accordance to the spatial planning terminology, in reference to areas potentially exposed to natural and anthropogenic (technological) hazards through their spatial proximity, or where such hazards occurred in the past. In most cases, these areas correspond to the non-aedificandi areas, where construction activities are prohibited by the provisions of different laws, originating from planning and other domains.

During the urbanization process, urban sprawl determines, due to the fact that the space is limited, the transformation of adjacent systems, natural or agricultural, into urban regions (Petrişor et al., 2010; Petrişor, 2012), affecting the natural environment (Peptenatu et al., 2012) and exposing the population to additional risks (Castañeda, 1989; Moore et al., 2003; Armaş and Gavriş, 2013). Furthermore, the environmental changes caused by urbanization increase the risks and create additional exposure (Zheng et al., 2013; Zhou and Zhao, 2013; Sharif et al., 2014; Bo, 2015; Guneralp et al., 2015; Zope et al., 2015). In theory, there are two types of risks, i.e., natural or artificial. The first group of risks includes tsunamis, floods, coastal erosion, settlement, landslides, earthquakes, epidemics, winds (e.g., cyclones, tornadoes, typhoons and hurricanes), desertification, volcanic eruptions, heat waves, avalanches, lightning, forest fires, blizzards and meteorite falls (Boştenaru-Dan, 2006; McGranahan et al., 2007; Boştenaru-Dan et al., 2014; Stan, 2014; Chen et al., 2015; Bouroumi et al., 2017; Adjim et al., 2018). The second group of risks includes industrial incidents causing explosions and pollution, incidents related to the transport and storage of electrical energy, gas and fuels, and incidents related to the transport of people and goods by road, sea, air and railroad (Vâlceanu et al., 2015; Capps et al., 2016; Mebirouk et al., 2018). These disasters result in human losses and economic, social, and environmental damages (Moore et al., 2003; Peptenatu et al., 2012; Armaş and Gavriş, 2013).

The multiplication of disasters has determined worldwide countries to fight against and attempt to reduce risks by prevention. One of the available instruments is planning, which can reduce the exposure and diminish the adverse outcomes if it is adequately enforced (Hutter et al., 2013; Jabareen, 2013; Macintosh, 2013; Renn and Klinke, 2013; Birkmann et al., 2014; Demichela et al., 2014; Friend et al., 2014; Highfield et al., 2014; Rivera and Wamsler, 2014; Zhai et al., 2014; Qin et al., 2015; Li et al., 2016). More precisely, in the French approach to planning, inspiring the spatial planning system of Romania and Algeria, the plans set specific construction rules applicable to different human 
activities (Petrişor, 2010), meant to reduce the risk exposure; plans rely on substantiation studies identifying the risks and areas prone to hazards. A common feature of Romania and Algeria is that, for different reasons (economic and political in Romania and political in Algeria) urban planning has become "derogatory", meaning that the development of a city occurs from exemptions from the planning provisions rather than in a planned manner (Taşcu-Stavre and Banică, 2014). Derogations make planning provisions ineffective in protecting the human population from different risks.

Prevention is based on the following principles: (1) knowledge and evaluation of different risks, modelling and mapping them by theme and region using GIS (Petrişor, 2014); the goal is to establish non-aedificandi zones and impose strict safety regulations on buildings based on the experiences of cities affected by disasters; (2) monitoring of risks by scientific bodies equipped with state-ofthe-art technological means that will trigger an alert in the event of a risk of a catastrophe; (3) adopting strategic plans to avoid and reduce risks in the context of sustainable development; (4) popularizing preventive information in order to involve citizens and improve their behaviour when facing risks; (5) building strategic infrastructure (food, tents, energy, water, medical, etc.); and (6) establish financial systems for disaster insurance, credit, aid and a special state budget.

\section{Problem and hypothesis}

Bejaia has suffered from several disasters including forest fires, landslides, floods and geo-technical disorders; some of them returned every year. Some of the most severe disasters are the earthquakes of 1860, 1865, 2000, 2006, 2012 and 2013 (Beldjoudi et al., 2009). In 2014, a leak at the oil pipeline caused a spill of 150,000 tons of hydrocarbons in the port of Bejaia. Another fire caused by lightning was recorded in 2016 at the level of the oil tank of the terminal of the Sonatrach unit; a part of the city of Bejaia would have disappeared causing many deaths without the rapid intervention of firefighters. Rock falls were also recorded at Aokas in 2015, in Tizi N'Berber in 2016, in Souk El Tenine and Amirouche Boulevard in 2017, resulting in many deaths and injuries (Nassim et al., 2017). As Bejaia is a mountainous region, landslides are frequent and cause a lot of damage, such as those of Ait Smail in 2009, Derguina, Taskriout, Ouedas (a bridge collapsed), Teghremt in 2012 and Toudja, Bouhamza, Feraoun and Amalou in 2015 (Bennia et al., 2016). Bejaia has always experienced floods in its history, but the phenomenon has been accentuated since 2007 due to climate changes (Chen et al., 2016). By 2015, some areas of the city were submerged up to $1 \mathrm{~m}$ high, especially in the industrial areas: Nassiria, Sghir district, Amriw and Aboudaw (Nouaceur et al., 2013).

Other natural disasters include geological disorders caused by the nature of the soil. Many buildings are cracked by differential settlements such as the Bejaia court that partially collapsed in 2011 (Lillouch et al., 2018). The city is also experiencing an essential advance of the sea and a steady erosion, especially in the Gulf of Bejaia (east side). Among the damages of this phenomenon, the most important is the destruction of the equestrian club, the agricultural fields 
and the camping village of Tichy (the sea has advanced $547 \mathrm{~m}$ ) in 2013 , and the partial destruction of the fishing port of Tala Ilef during the same year (Ayadi et al., 2016; Bachari et al., 2017; Djouder and Boutiba, 2017).

Other disasters in Bejaia are caused by the activities of human beings; they include pollution (Moulai et al., 2008; Alkama et al., 2006), forest fires and accidents. The first ones affected the air (Alkama et al., 2009), the sea, the rivers, the water table, the fauna and the flora. They were generated by the activities located within the industrial zone located in the middle of the city, which dumped its waste directly into the rivers (especially Sghir) without prior treatment. Household sewage was also discharged into rivers like into an open pit. The other industrial zones of Akbou, Sidi Aiche and El Kseur, which move away from Bejaia 60, 40 and 25km respectively, also discharge their untreated waste, brought to Bejaia by the great river of Soummam (Yalaoui-Guellal et al., 2018). This river pollutes in its turn the sea. The second type of disasters consists of forest fires, usually triggered by people (Meddour-Sahar and Derridj, 2012). The biggest ones are those of 2016 where 2,200 hectares of forests were ravaged. Even the Gouraya Nature Reserve, located near the city, lost 165 hectares. In addition to these, numerous accidents occurred on national roads No. 12 and No. 9 due to the trucks leaving the depots and factories. On the unguarded level crossings of Bir Selam, many trains crashed into people and vehicles (Hidra and Kaid Tlilane, 2014).

These observations led to the following questions: What are the multiple risks threatening the city of Béjaia and which of them are the most dangerous? Does the urban configuration comply with the regulations on risk prevention? If not, what are the reasons for this infringement? The hypothesis is that the city is threatened by many natural and artificial risks and that the configuration of the city does not comply with the risk prevention regulations; thus, the situation is due to illegal constructions and planning.

The similarity between the Algerian and Romanian planning systems and derogatory urban planning is at the core of the cooperation resulting into the present study. Its novelty consists of addressing these issues in the particular political context, providing new insights on the potential risk of sacrificing the long-term safety of population for short-term political aspirations, and its originality consists of using the case study of Bejaia, Algeria, insufficiently discussed in literature, despite it being a representative example of the issue presented in the article. Furthermore, the article brings additional evidence to the fact that the contribution of planning to the reduction of risk exposure takes effect only if the planning provisions are appropriately enforced. Such evidence is particularly relevant from a practical perspective, documenting the possible adverse outcomes of derogatory planning.

\section{Materials and methods}

\section{Presentation of the study area}

Bejaia is located at $238 \mathrm{~km}$ east of the capital of Algiers. It is part of the Kabylia region. It is bounded by the Mediterranean Sea to the north, by Jijel in the East, 
by Tizi Ouzou and Bouira to the West, by Setif and Bordj Bou Arreridj to the South. The Department of Bejaia is crossed by three mountain chains, i.e., the Djurdjura, the Babors and the Bibans. The mountainous area constitutes $75 \%$ of the total area of the Department.

The chief town of the department, which is our case study, is bounded by the municipalities of Toudja and Oued Ghir in the West, the municipalities of Boukhelifa and Tala Hamza in the South, the Mediterranean Sea in the North and the East. Its urbanized area covers 2,401.73 hectares. The city is built in the form of an amphitheatre. It consists of a plain that overlooks the sea and is surrounded by three mountains: Gouraya in the north, which is also a natural park classified by UNESCO (670m above sea level), Sidi Bouderhem in the south (300m above sea level) and Bouaiche (260m above sea level) to the west.

From the historical point of view, the city of Bejaia suffered from many consequent occupations, by the Phoenicians, Romans (33 BC), Vandals (428 AD), Arabs (7th century), Spaniards (1509-1555), Turks (1555-1883) and French (1883-1962). The indigenous Berbers dynasties who governed Bejaia during the Muslim era (1067-1509) are the Hammadites, Almohades (Hamma and Petrişor, 2017), and Hafsides (Hamma, 2018b). The city had 61 hectares towards the end of the Turkish occupation to pass to 210 hectares after the exit of the French. After the independence of Algeria, 2,191.73 hectares of new urban tissue were built in response to the rapid demographic growth (Axxam SCPA, 2016).

\section{Assessment and causes of risks}

To answer the research questions and test the hypothesis, first all the risks that threaten the city of Bejaia were modelled on four maps that concern natural risks and risks related to road and rail transport, to the transportation and storage of energy and hydrocarbons, and to the industry.

The second step was to check the conformity of the urban configuration of the city with the risk prevention regulations in force, which establish nonaedificandi zones (NAZ) (Hamma, 2018a), presented in Table 1. This regulation is mentioned in the Algerian laws which are published in the official journal of the Republic and cited in the result part.

The Algerian earthquake regulations prohibit building at the foot of the slopes and steep slopes. It also introduces special constructive provisions for buildings built on unstable soils. The environmental protection act requires the treatment of wastewater from factories and homes before being poured into rivers and the sea.

The third step consisted of computing the number of buildings located in NAZ and threatened by risks (the number of affected buildings is shown in Tables 2, 3 and 4 depending on the nature of the risk), and the percentage of threat for each type of risk (Table 5 in the results section) using the following formula:

$$
\begin{gathered}
\text { Percentage of } \\
\text { the type of risk }
\end{gathered}=100 \times \frac{\begin{array}{c}
\text { Number of buildings threatened by that type } \\
\text { of risk or located in that type of NAZ }
\end{array}}{\begin{array}{c}
\text { Total number of buildings threatened } \\
\text { by all risks or located in all NAZ }
\end{array}}
$$


Table 1. Width of non-aedificandi zones (NAZ) in Algeria, based on the national laws.

\begin{tabular}{lll}
\hline \multicolumn{1}{c}{ Feature from which the NAZ is established } & \multicolumn{1}{c}{ Width } & \multicolumn{1}{c}{ Mentions } \\
\hline Either side of the river boundary & $15 \mathrm{~m}, 35 \mathrm{~m}$, and $75 \mathrm{~m}$ & $\begin{array}{c}\text { Depends on the water } \\
\text { flow }\end{array}$ \\
Limit of the forest & $500 \mathrm{~m}$ for dwellings, \\
$1,000 \mathrm{~m}$ for factories & $100 \mathrm{~m}$ \\
Either side of the limit of the seismic fault & $300 \mathrm{~m}$ & \\
Coastline & $100 \mathrm{~m}$ & \\
Either side of the highway limit & $35 \mathrm{~m}$ & Minimum $15 \mathrm{~m}$ height \\
Both sides of the national road and bypass limits & mandatory \\
Each side of the limit of the departmental road & $15 \mathrm{~m}$ & \\
Each side of the boundary of the municipal road & $10 \mathrm{~m}$ & \\
Either side of the railway lines & $35 \mathrm{~m}$ & \\
Either side of the line limit of the cableway & $15 \mathrm{~m}$ & \\
Either side of the gas pipeline boundary & $75 \mathrm{~m}$ & \\
Limit of the gas storage area & $1,000 \mathrm{~m}$ & \\
Either side of the high voltage line & $45 \mathrm{~m}$ & \\
Either side of the medium voltage line & $20 \mathrm{~m}$ & \\
Limit of the higher voltage transformer station & $500 \mathrm{~m}$ & $75 \mathrm{~m}$ \\
Either side of the oil pipeline boundary & $1,000 \mathrm{~m}$ & $100 \mathrm{~m}$ \\
Limit of the hydrocarbon storage area & $1,000 \mathrm{~m}$ & \\
Limit of the petrol station & $500 \mathrm{~m}$ & \\
Limit of the industrial area & & \\
Limit of the semi-industrial area &
\end{tabular}

Source: Algerian laws no. 90-29 / no. 84-12/ no. 02-02 / no. 85-36 / no. 90-35 / no. 03-10 / no. 84-55

Risks were assessed based on the number of buildings affected and ranked with the highest value corresponding to the most dangerous risk. The final step was to investigate the legal (legal or illegal) and ownership (private or public) statuses of the buildings in order to determine the drivers of urbanisation (population or decision-makers). Moreover, the sources of pollution in the city of Bejaia were identified.

\section{Results and discussion}

In terms of natural risks, Bejaia is threatened by floods, forest fires, geotechnical disorders, upwelling of water, seismic faults, landslides, encroachment on the sea and coastal erosion. These risks are grouped in the map displayed in Figgure 1 and Table 2.

The floods are caused by the massive winter rains and by the passage of nine rivers. The buildings do not respect the $75 \mathrm{~m}$ setback from the Soummam river boundary and $35 \mathrm{~m}$ for the other eight rivers. Consequently, 2,376 constructions are threatened by the overflowing of the rivers and are violating article no. 47 of Law no. 90-29/December 1, 1990 on spatial and urban planning. Many houses are built in the non-aedificandi area with a width of $500 \mathrm{~m}$ (established by article no. 27 of Law no. 84-12/June 23, 1984 on the general system of forests) due to forest fires or threatened by landslides due to the fact that the city is surrounded by mountainous chains with a steep slope ranging between $21 \%$ and $83 \%$.

Moreover, the oil port is also threatened by forest fires because the oil tanks are located within $100 \mathrm{~m}$ of the forest while the regulation (law no. 84-12 mentioned above) provides $1000 \mathrm{~m}$ for industrial installations. Bejaia has an 1,140 hectares flat area with heterogeneous soil, containing marl. This zone also has groundwater and is crossed by all the rivers of the city, which generates the 


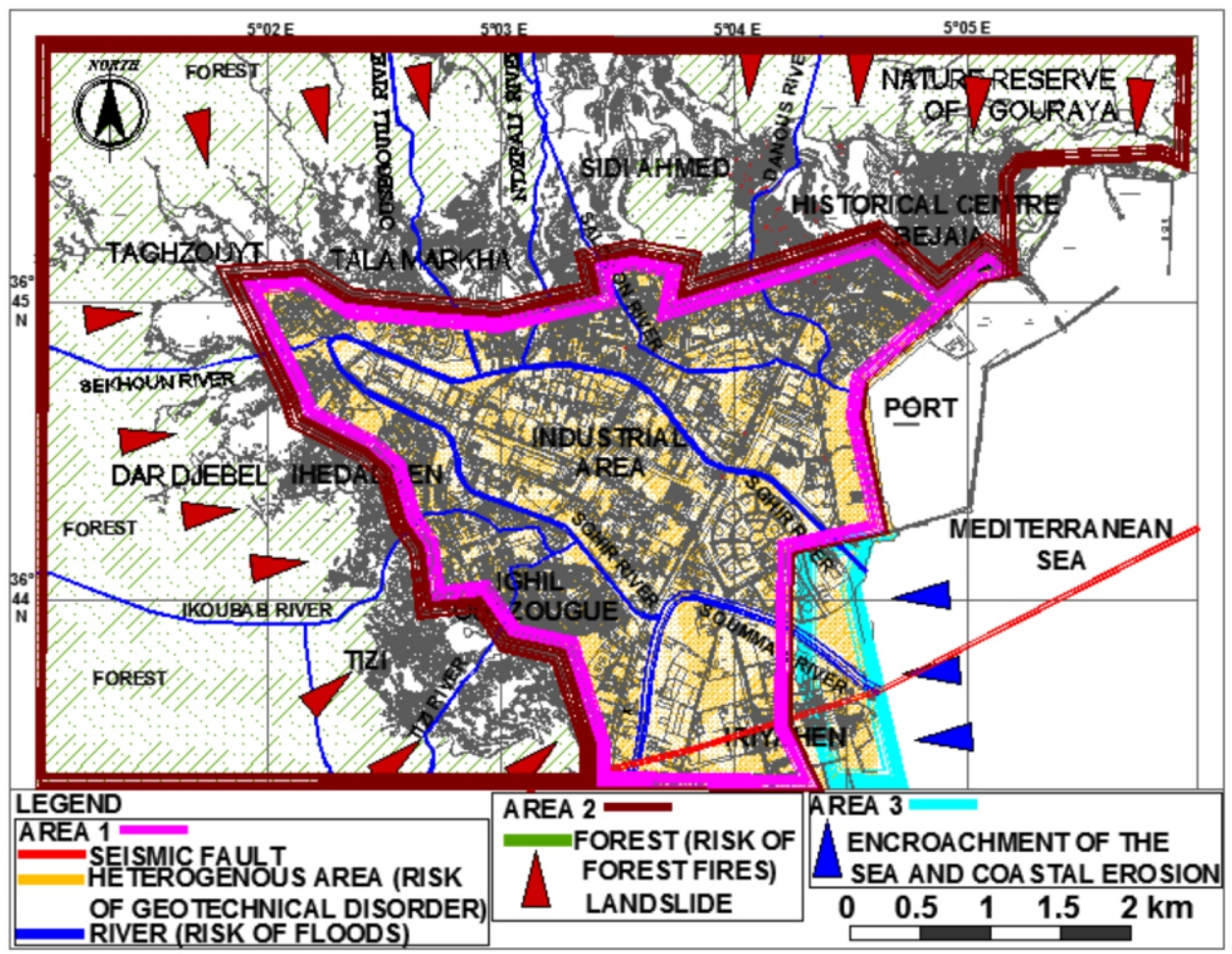

Figure 1. Natural risks threatening Bejaia

Source: Maps taken from the master plan of Béjaia, 2016 and modified by the authors

upwelling of water. These factors have led the planning authorities to classify it as a zone at risk of settlement in accordance with the decree of January 4, 2000 approving the technical, regulatory document on Algerian para-seismic rules (RPA99). Several constructions are cracked. In total, 19,004 buildings are threatened by geo-technical disorders.

The study area is crossed by an active seismic fault of $2,649 \mathrm{~m}$, which continues its way to the sea in the east and Soummam valley in the southwest. The concerned districts where buildings are within a $200 \mathrm{~m}$ wide non-aedificandi zone (decree of January 4, 2000, mentioned above) are Sidi Ali Labher, Iriyahen and Bir Selem. Bejaia also suffers from the effects of the rise of the sea and erosion of the littoral since it has a vast gulf with strong currents. The study area has a beach of 1,746m; 1,069 constructions are at 713m of it in Sidi Ali Labher and do not observe the recoil of $300 \mathrm{~m}$ of the coastline set by article no. 18 of the Law no. 02-02/February 5,2002 on the protection and development of the littoral. The airport of Bejaia is also threatened, as part of the airstrip is built in the open sea.

Concerning road and rail transport risks (Figure 2), the city is crossed by three national roads, a departmental road and a municipal road. Bejaia also has a bypass and a railway that runs through the city in the middle and connects it to the capital Algiers. Four level crossings exist in the city; two are guarded in the rear harbour and the four roads, and two are unguarded, located in Bir Selem. In summary, Table 3 shows the number of buildings potentially affected by each road and rail transport risk in the neighbourhoods of Bejaia. These 
Table 2. Number of buildings potentially affected by natural risks in the neighborhoods of Bejaia

\begin{tabular}{|c|c|c|c|c|c|c|}
\hline Neighborhood & Floods & $\begin{array}{l}\text { Forest } \\
\text { fires }\end{array}$ & $\begin{array}{l}\text { Geotechnical } \\
\text { disorders }\end{array}$ & $\begin{array}{l}\text { Land- } \\
\text { slides }\end{array}$ & $\begin{array}{c}\text { Seismic } \\
\text { fault }\end{array}$ & $\begin{array}{l}\text { Coastal } \\
\text { erosion }\end{array}$ \\
\hline Tizi & 132 (Tizi river) & 6,267 & - & 1,253 & - & - \\
\hline Taklet & - & 2,922 & - & 584 & - & - \\
\hline Dar Djebel & - & 5,552 & - & 1,110 & - & - \\
\hline Ighil Ouatou & 78 (Sekhoun river) & 3,722 & - & 744 & - & - \\
\hline Taghezout & - & 2,788 & - & 557 & - & - \\
\hline Ibidhatemen & - & 2,655 & - & 424 & - & - \\
\hline Tala Markha & 164 (Ousegouili river) & 3,973 & 4,162 & 1,742 & - & - \\
\hline Ighil Oumirou & $\begin{array}{c}-10 \\
-1\end{array}$ & 3,255 & - & 124 & - & - \\
\hline Sidi Ahmed & 369 (Solomon river) & 3,042 & - & 811 & - & - \\
\hline Tala Ouariane & - & 2,965 & - & 734 & - & - \\
\hline Dar Nasar & - & 3,727 & - & 1,476 & - & - \\
\hline Taessast & 85 (Danous river) & 967 & - & 264 & - & - \\
\hline Sidi Ouali & - & 1,580 & - & 651 & - & - \\
\hline Rabah Amkhoukh & - & 1,347 & - & 884 & - & - \\
\hline Sidi Bouali & - & 1,835 & - & 396 & - & - \\
\hline Sidi Ali Labher & - & - & 578 & - & 339 & 1,069 \\
\hline Iriyahen & 54 (Soummam river) & - & 315 & - & 185 & - \\
\hline Bir Selem & - & - & 264 & - & 103 & - \\
\hline Ighil Ouazougue & 101 (Tizi river) & - & 3,523 & - & - & - \\
\hline lhedadden & 224 (Ikoubab river) & - & 3,894 & - & - & - \\
\hline Takheribth & 98 (Sekhoun river) & - & 412 & - & - & - \\
\hline Targua Ouzamour & - & - & 575 & - & - & - \\
\hline Industrial area & 203 (Sghir river) & - & 253 & - & - & - \\
\hline Port & 5 (Danous river) & - & 104 & - & - & - \\
\hline Quatre Chemins & - & - & 384 & - & - & - \\
\hline Nassiria & 350 (Sghir river) & - & 2,291 & - & - & - \\
\hline Lakhemis & 80 (Danous river) & - & 2,342 & - & - & - \\
\hline Administrative city & - & - & 53 & - & - & - \\
\hline Dallas & - & - & 1,809 & - & - & - \\
\hline Sghir & 202 (Sghir river) & - & 1,090 & - & - & - \\
\hline The sports complex & - & - & 14 & - & - & - \\
\hline Imezzaine & - & - & 103 & - & - & - \\
\hline Aamriw & 155 (N'Defali river) & - & - & - & - & - \\
\hline Souk El Asser & 76 (Danous river) & - & - & - & - & - \\
\hline
\end{tabular}

Source: Authors, 2016

Table 3. Number of buildings potentially affected by road and rail transport risks in the neighborhoods of Bejaia

\begin{tabular}{|c|c|c|c|c|c|c|c|}
\hline Neighborhood & $\begin{array}{c}\text { National } \\
\text { road } \\
\text { no. } 09\end{array}$ & $\begin{array}{l}\text { National } \\
\text { road no. } \\
12\end{array}$ & $\begin{array}{l}\text { National } \\
\text { road no. } \\
24\end{array}$ & $\begin{array}{l}\text { Departmental } \\
\text { road no. } 136\end{array}$ & $\begin{array}{l}\text { Municipal } \\
\text { road }\end{array}$ & $\begin{array}{l}\text { By- } \\
\text { pass }\end{array}$ & $\begin{array}{l}\text { Rail- } \\
\text { way }\end{array}$ \\
\hline Tala Ouariane & - & - & 43 & - & 22 & - & - \\
\hline Dar Nasar & - & - & - & - & 50 & - & - \\
\hline Taessast & - & - & - & - & 16 & - & - \\
\hline Sidi Ouali & - & - & - & - & 17 & - & - \\
\hline Sidi Bouali & - & - & - & 51 & - & - & - \\
\hline Iriyahen & 15 & - & - & - & - & - & - \\
\hline Bir Selem & - & 72 & - & - & - & - & 753 \\
\hline Ighil Ouazougue & - & - & - & - & - & 309 & - \\
\hline Industrial area & - & - & - & - & - & - & 216 \\
\hline Port & - & - & - & - & - & - & 438 \\
\hline Quatre Chemins & 13 & 25 & - & - & - & - & 320 \\
\hline Lakhemis & - & - & - & - & & 103 & - \\
\hline Aamriw & - & - & 91 & - & - & - & - \\
\hline Sidi Touati & - & - & - & - & 15 & - & - \\
\hline
\end{tabular}

Notes:

National road no. 09 which connects Béjaia to Sétif

National road no. 12 which connects Bejaia to Tizi-Ouzou via El Kseur

National road no. 24 which connects Bejaia to Tizi-Ouzou by the littoral. A departmental road Departmentalroad no. 136

connects the city center with the Zigouat beach

The municipal road connects the city center to Fort Gouraya 


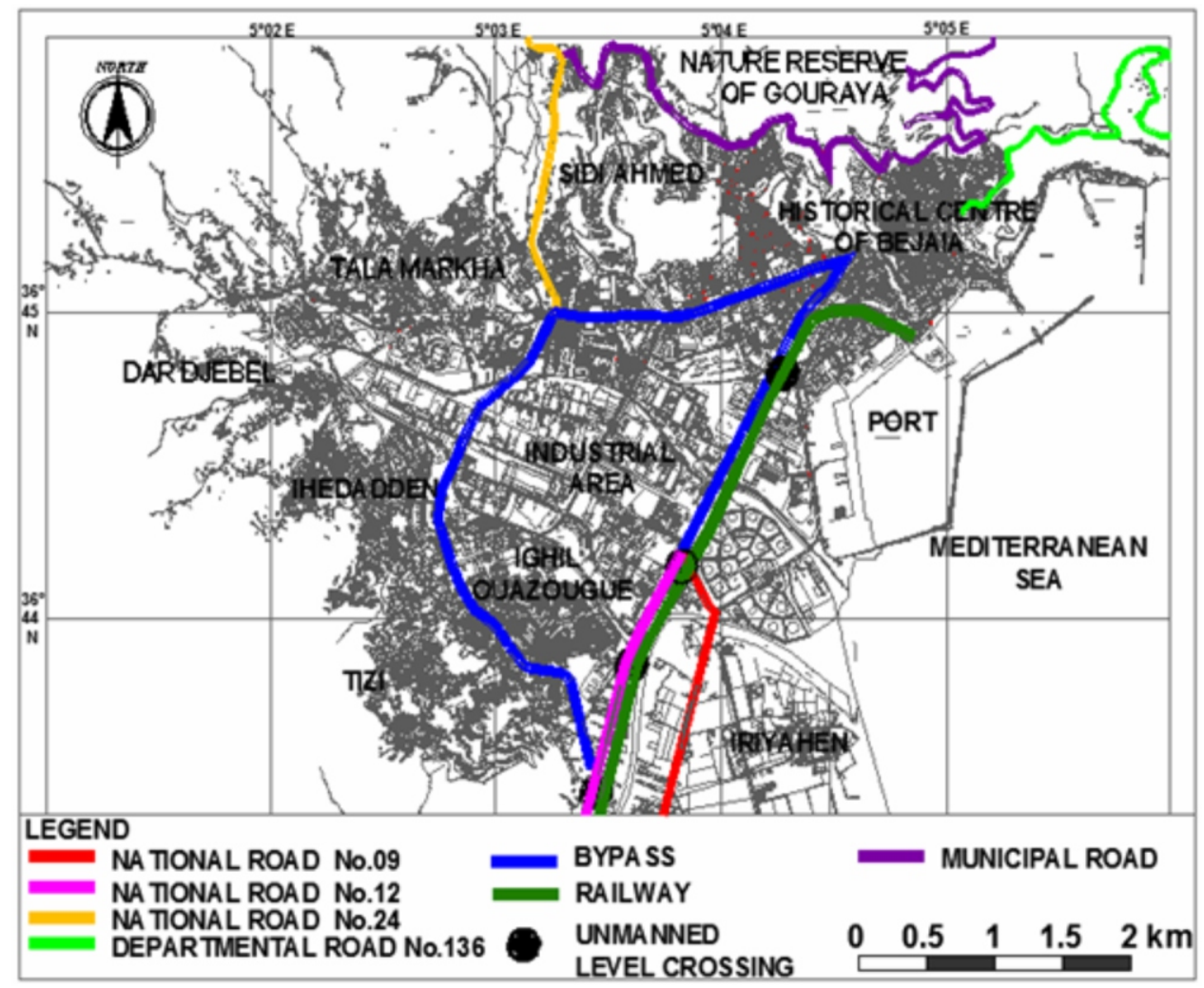

Figure 2. Road and rail transport risks threatening Bejaia

Source: Maps taken from the master plan of Béjaia, 2016 and modified by the authors

constructions violate article no. 15 of Decree no. 85-36/February 23, 1985 on motorways, which requires a $35 \mathrm{~m}$ buffer on both sides of national and bypass roads, $15 \mathrm{~m}$ for departmental roads and $10 \mathrm{~m}$ for municipal roads. Article no. 4 of Law no. 90-35/December 25, 1990 on the police, safety, and railway transport safety, establishing a $35 \mathrm{~m}$ buffer on both sides of railways, is infringed too.

At the level of the NR9, 28 buildings are constructed less than $35 \mathrm{~m}$ from the road limit for a length of $509 \mathrm{~m} .97$ buildings are in breach on the boundaries of the NR12 over a distance of 1,951m. On the banks of the NR24, 134 buildings are built in the non-aedificandi zone for a length of 1004 m. In Sidi Bouali, 51 buildings do not respect the distance of $15 \mathrm{~m}$ from the limit of the departmental road for a length of $516 \mathrm{~m}$. On both sides of the municipal road, 120 buildings do not respect the $10 \mathrm{~m}$ setback over a distance of $2,328 \mathrm{~m}$. Throughout the bypass, 412 buildings are less than $35 \mathrm{~m}$ from this road. On both sides of the railway, 34 buildings are constructed in the non-aedificandi zone of a width of $35 \mathrm{~m}$ over a distance of $1727 \mathrm{~m}$. This passage starts from the roundabout of Quatre Chemins until the end of Bir Selem. It also has two unguarded crossings on the latter, which cause numerous accidents. This is against section 13 of Law no. 90-35 mentioned above, requiring a surveillance station for all level crossings within the urban areas.

Bejaia is also threatened by the risks related to the transport and storage of energy and hydrocarbons (Figure 3), as it has several networks that pass through its urban fabrics. The city has a gas pipeline, an oil pipeline, a gas 


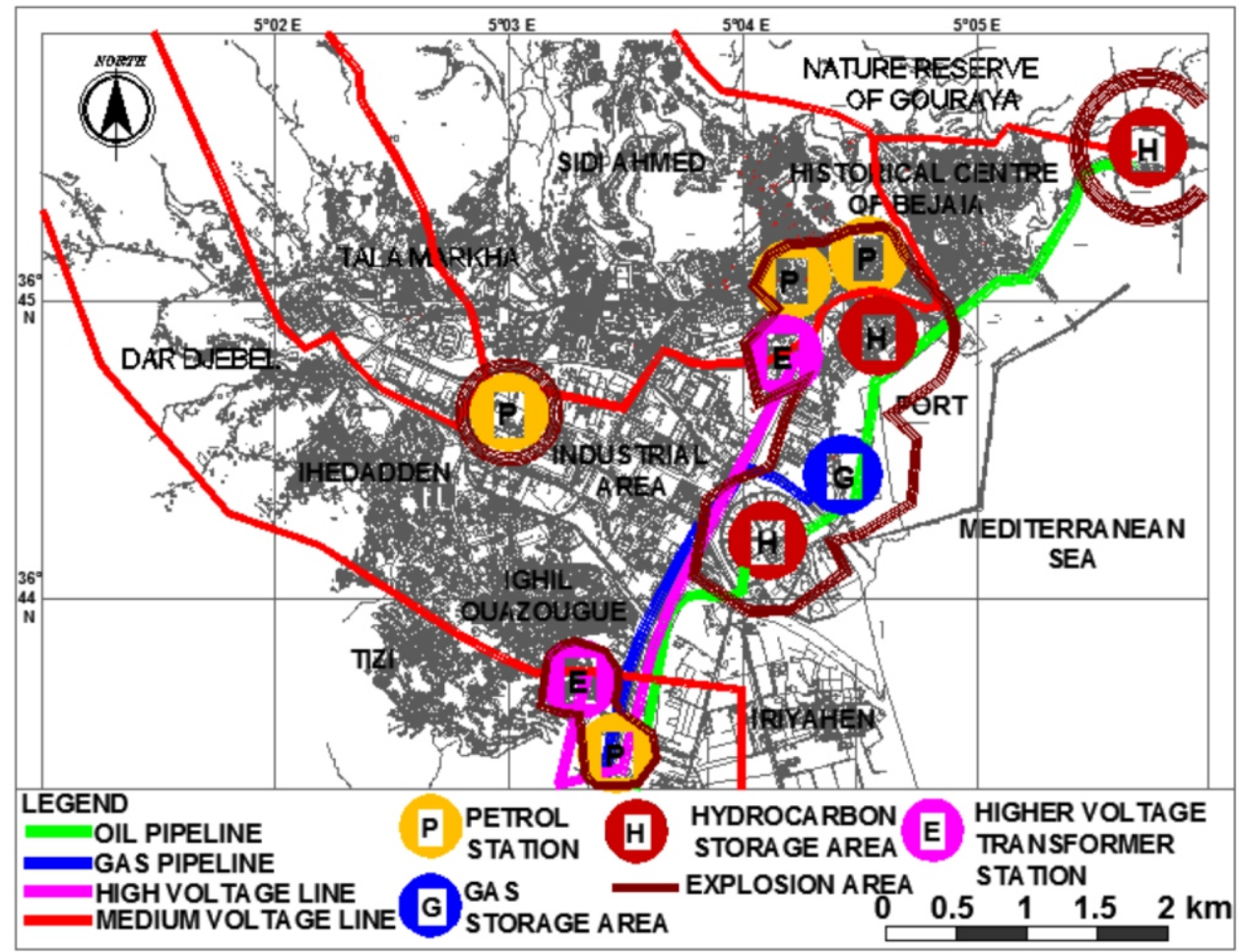

Figure 3. Transport and storage of energy and hydrocarbons risks threatening Bejaia Source: Maps taken from the master plan of Béjaia, 2016 and modified by the authors

storage area, three hydrocarbon storage areas, a high voltage line, six medium voltage lines, two higher voltage transformer stations and four petrol stations. All these risks are also presented in Table 4, displaying the number of buildings potentially affected by each risk in the neighbourhoods of Bejaia. These buildings violate the inter-ministerial decree of June 14, 2011, which sets out the limits and conditions for occupying the protection perimeter around electricity and gas transport lines and storage installations. The latter establishes buffers of $75 \mathrm{~m}$ for gas pipelines, $45 \mathrm{~m}$ for high voltage lines, $20 \mathrm{~m}$ for medium voltage lines, $1,000 \mathrm{~m}$ for gas storage stations, and $500 \mathrm{~m}$ for high voltage transformer stations The decree of January 15, 1986, fixing the protection limits of hydrocarbon facilities and infrastructures, was also infringed; this law sets buffers of $75 \mathrm{~m}$ for oil pipelines, $100 \mathrm{~m}$ for petrol stations, and $1,000 \mathrm{~m}$ for hydrocarbon storage stations.

The findings show that 21 buildings do not respect the distance of $75 \mathrm{~m}$ of the oil pipeline over a distance of $2,327 \mathrm{~m}$. On both sides of the gas pipeline, 59 buildings are less than $75 \mathrm{~m}$ over a length of $1,190 \mathrm{~m}$. Within a radius of $1,000 \mathrm{~m}$ from the gas storage station, 25 residential buildings, port facilities (67 buildings), two hydrocarbon storage stations and five factories are in real danger, among which the biggest African edible oil production complex. The areas to be affected are those of the Sub-port and Quatre Chemins.

The Hydrocarbon Storage Stations in Quatre Chemins, Brise de Mer and the Sub-port are true delayed-explosion bombs. The first contains 16 large trays; in case of explosion, it will shave 314 hectares of an industrial zone (69 buildings), 
Table 4. Number of buildings potentially affected by transport and storage of energy and hydrocarbons risks in the neighborhoods of Bejaia

\begin{tabular}{|c|c|c|c|c|c|c|c|c|}
\hline Neighborhood & $\begin{array}{l}\text { Oil } \\
\text { pipe- } \\
\text { line }\end{array}$ & $\begin{array}{l}\text { Gas } \\
\text { pipe- } \\
\text { line }\end{array}$ & $\begin{array}{c}\text { Gas } \\
\text { storage } \\
\text { station } \\
\end{array}$ & $\begin{array}{c}\text { Hydrocarbon } \\
\text { storage } \\
\text { stations }\end{array}$ & $\begin{array}{c}\text { High } \\
\text { voltage } \\
\text { lines } \\
\end{array}$ & $\begin{array}{c}\text { Medium } \\
\text { voltage } \\
\text { lines }\end{array}$ & $\begin{array}{l}\text { High voltage } \\
\text { transformer } \\
\text { stations }\end{array}$ & $\begin{array}{l}\text { Petrol } \\
\text { stations }\end{array}$ \\
\hline Sidi Bouali & & & & 291 & & & & \\
\hline Bir Selem & 15 & 59 & - & - & 51 & - & 182 & 1 \\
\hline Ighil Ouazougue & - & - & - & - & - & - & 602 & - \\
\hline Industrial area & - & - & 7 & 69 & 100 & - & 51 & \\
\hline Port & - & - & 67 & 244 & & - & 74 & 31 \\
\hline Quatre Chemins & - & - & 25 & 60 & 62 & - & - & - \\
\hline Lakhemis & - & - & - & 1,030 & - & - & 1,400 & 78 \\
\hline Brise de mer & 6 & - & - & & - & - & - & - \\
\hline Old center & - & - & - & 1,021 & & - & - & - \\
\hline Tizi & - & - & - & - & - & 283 & - & - \\
\hline Tala Markha & - & - & - & & - & 113 & - & - \\
\hline $\begin{array}{l}\text { Administrative } \\
\text { area }\end{array}$ & - & - & - & - & - & - & 49 & - \\
\hline Edimco & - & - & - & - & - & - & - & 1 \\
\hline
\end{tabular}

Source: Authors, 2016

10 factories and its 60 houses. The second station contains 4 large trays and 5 small trays. In case of explosion, it will ravage the natural park of Gouraya located in the north of the latter, 342 houses and the export terminal oil. The third station contains 5 small trays, but it is the most dangerous given its location in the middle of the city, unlike the other two which are on the outskirts. 2,234 buildings and all port facilities will be affected in case of an explosion. The figures are computed based on counting the number of buildings situated within a $1,000 \mathrm{~m}$ radius from the centre of an explosion. The size of the radius was computed according to the standards of the National Society for Research, Production, Transport, Processing and Marketing of Hydrocarbons.

On both sides of the high voltage line from Bir Selem to the Sub-port, 162 buildings are built within $40 \mathrm{~m}$ on a length of $3,254 \mathrm{~m}$. On the one that goes from Bir Selem to Ighil Ouazougue, 51 buildings are in violation on a length of $810 \mathrm{~m}$. On the banks of the medium-voltage lines, 396 buildings are less than $20 \mathrm{~m}$ from the latter, on distances of $2,971 \mathrm{~m}$. The two high voltage transformer stations of Remela and the Sub-port pose a danger for the city since many buildings are constructed in the non-aedificandi zone on a radius of $500 \mathrm{~m}$. The first station has 784 residential buildings and the second station has 1,570 residential buildings, an administrative area and three factories.

Bejaia has four petrol stations located in Edimco, Bir Selem, Sub-port and Lekhemis. Within a radius of $100 \mathrm{~m}, 111$ buildings are in violation of the urban planning regulations, i.e., a hotel next to the first station, a milk factory next to the second, 31 buildings next to the third and 78 buildings next to the fourth.

The city has an industrial area of 403 hectares (Figure 4), or 1/3 of the total area of the urbanised area of Bejaia. Its central location and the crossing of several rivers on its territory increase the risk of industrial incidents. The soil on which is built is marshy and has groundwater. This area has high-pollution factories. Some dump their wastes directly into the Sghir River, which are the Adrares Ceramic Factory, the Quatre Chemins soap factory and the edible oil Factory of Aures Boulevard. The edible oil Factory located at the port discharges its waste directly into the sea. These factories violate Law no. 03-10/July 19, 


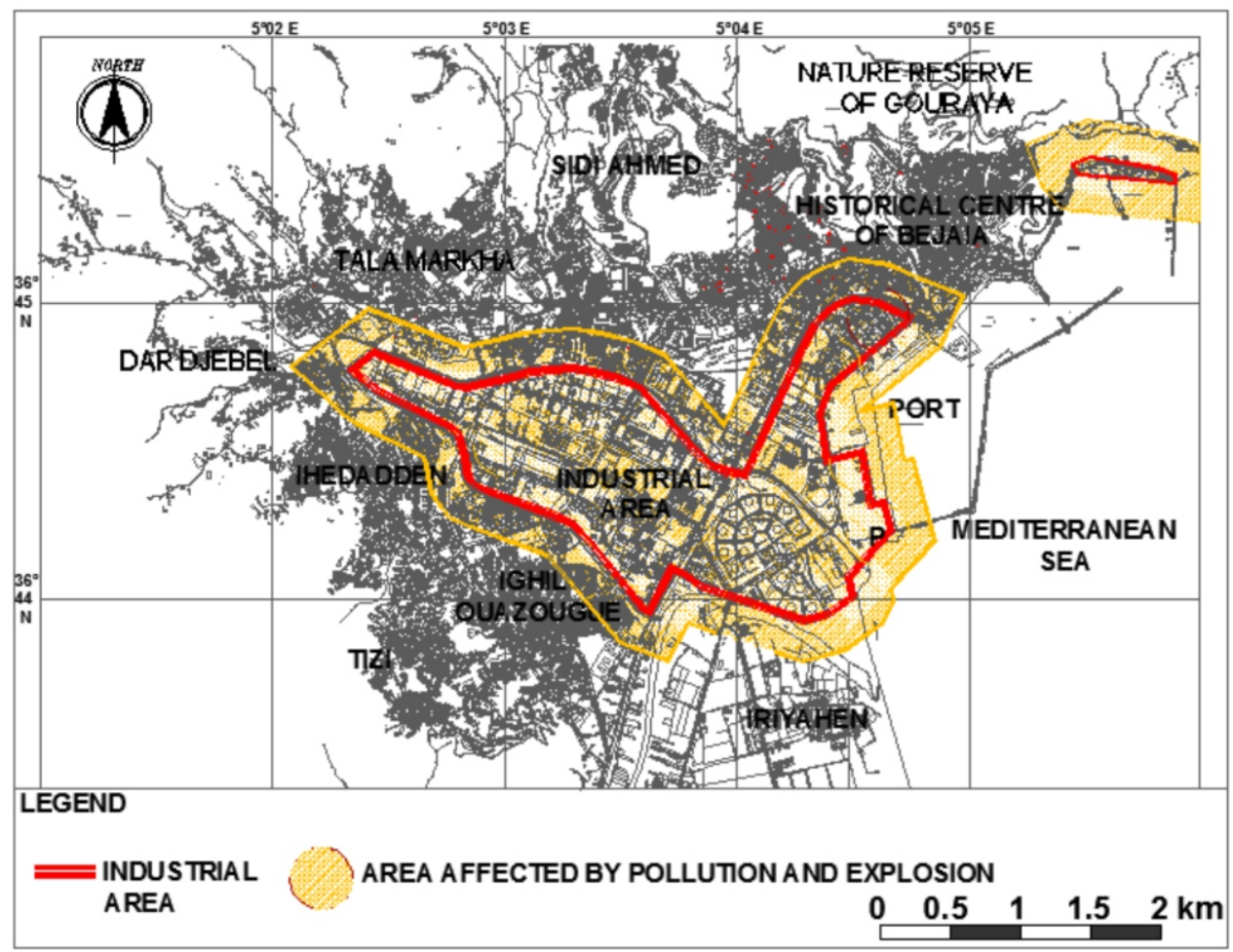

Figure 4. Industrial risks threatening Bejaia

Source: Maps taken from the master plan of Béjaia, 2016 and modified by the authors

2003 on environmental protection, which requires the treatment of wastewater from factories before pouring it into rivers and the sea; toxic waste must be collected and transferred to industrial landfill or incineration centres. This area, as mentioned before, has three hydrocarbon storage stations, one gas storage station and two higher voltage transformer stations, which are sources of pollution and explosion, especially since they are very close to each other. In the non-aedificandi zone (radius of 1,000m set by Decree no. 84-55/March 3, 1984 on the administration of industrial zones) which surrounds the industrial zone, 15,832 buildings are constructed against the law.

Overall, 103,971 buildings are built in areas at risk (Table 5). The most threatening natural risks are forest fires (44.82\%), and most the essential artificial risk is the sprawl of the industrial zone (15.24\%). Other important natural risks are geo-technical disorders due to the swampy nature of the soil $(18.27 \%)$ and landslides due to the mountainous character of the city $(11.30 \%)$. Among the constructions built within the risk areas, 31,191 (29.99\%) buildings are legal, and 72,780 (70.01\%) are illegal. 4,589 (14.71\%) legal structures belong to the state and $26,602(85.28 \%)$ are private, stressing out the involvement of politicians, planners and control agencies in the issuance of building permits that generated this chaotic situation.

Among the illegal constructions, 14,542 (19.98\%) acquired a legal status through Law no. 08-15/July 20, 2008 on the rules of conformity for constructions and their completion. Essentially, this law encourages illegal structures, and was promulgated in order to reduce social unsettledness. Bejaia is part of 
Table 5. Number of buildings exposed to different risks in Bejaia.

\begin{tabular}{lcc}
\hline Risk & No. of buildings & Percentage \\
\hline Floods & 2,376 & 2.29 \\
Forest fires & 46,597 & 44.82 \\
Geotechnical disorders & 19,004 & 18.27 \\
Seismic faults & 627 & 0.60 \\
Landslides & 11,754 & 11.30 \\
Encroachment of the sea and coastal erosion & 1,069 & 1.03 \\
Skidding of cars & 842 & 0.81 \\
Train derailments & 34 & 0.03 \\
Electrocution & 2,967 & 2.85 \\
Explosions of the hydrocarbons and gas & 2,789 & 2.68 \\
storage stations & 80 & 0.08 \\
Oil and gas pipeline explosions & 15,832 & 15.24 \\
Explosion of the industrial zone & & \\
\hline
\end{tabular}

Source: Authors, 2016

the rebel Berber region of Kabylia, which has the most significant number of illegal constructions in Algeria. This is encouraged by the silence of decisionmakers who can not meet the increasing housing demand determined by the rapid growth of population. Senior officials are also afraid of an uprising of the Kabylian population, which revolted against the state in 1963, 1980, 1988, 1995, 1998, 2001, and 2004, and also commemorates the uprisings every year, increasing the risks for repeating them at any time.

The provisions of the spatial plan of the shoreline of Bejaia are not observed, which constitutes a violation of the law 02-02 of February 05, 2002 on the protection and valorisation of the littoral. This plan defined the polluting areas and planned to transfer all hazardous activities (industrial and hydrocarbon storage areas) and build new wastewater treatment plants. Also, it established a $300 \mathrm{~m}$ retreat of buildings and included provisions for demolishing all the buildings built within this area by the political mafia. Unfortunately, the Mayor and Prefect of Bejaia did not sign the following demolition orders.

\section{Conclusion and Recommendations}

At the end of this research, it is necessary to draw a balance and synthesise the different aspects analysed. First of all, the city was not found in conformity with the legal framework in force (although the Algerian regulations contain all riskrelated provisions), because numerous buildings are built in areas at risk. Second, the findings indicate that natural risks $(78.31 \%)$ are more threatening than artificial risks (21.69\%). Third, decision-makers are accomplices to this illegal situation, because they have built public buildings, social houses and factories $(4,589$ or $4.41 \%)$, issued building permits $(26,602$ or $25.58 \%)$, and allowed for the proliferation of illegal constructions (72,780 or 70.01\%).

Overall, planning can help to reduce urban risks, if it is adequately enforced. The environmental impact assessment should define the required buffers and mitigate all risks according to the Executive Decree no. 90-78/February 27, 1990 on the environmental impact assessment. Therefore, in order to limit these risks, it is necessary to observe the urban planning regulations related to risk 
prevention and to apply the provisions of the management plan, part of the master plan of Bejaia, i.e.: (1) relocation of the industrial zone towards El Kseur; (2) relocation of hydrocarbons and gas storage areas to Sidi Ali Labehar; (3) relocation of high voltage transformer stations to Oued Ghir; (4) forest clearing over a $500 \mathrm{~m}$ wide area surrounding the buildings; (5) construction of a new sewage treatment plant in Sidi Ali Labher; (6) demolition of illegal constructions which approach rivers; (7) relocation of medium and high voltage lines; (8) demolition of constructions which approach gas and oil pipelines; and (9) taking constructive precautions for buildings in areas with steep slopes or geo-technical disorders.

Finally, the decision-makers are responsible for enforcing and observing the laws, as the inhabitants are building houses in order to meet their housing needs, which the state was not able to meet, but instead took advantage of the silence of competent authorities.

Among the actors who must contribute to the prevention of risks, the most important are the Direction of Forests (fires and landslide), Town Planning Police (offenses), national maritime authorities (protection of the coast against the pollution produced by boats), Direction of Urban Planning (urban plans), Direction of the Environment (fight against pollution and protection of natural sites), Direction of Waters (water treatment), Bejaia City Hall (building permit, demolition orders, and hygiene), and Prefecture of Bejaia (building permits and demolition orders).

\section{References}

Adjim, H., Djedid, A. and Hamma, W. (2018), "Urbanism, climate change and floods: Case of Tlemcen city", Urbanism Architecture Constructions, vol. 9, no. 1, p. 71-80.

Alkama R., Adjabi S., Ait-Idir F. and Slimani Z. (2006), "Air Pollution in Bejaia City (Algeria): Measurements and Forecasts", Polish Journal of Environmental Studies, vol. 18, no. 5, p. 769-773.

Alkama, R., Ait-Idir F. and Slimani, Z. (2006), "Estimation and measurement of the automobile pollution: Application to Bejaia case", Global Nest Journal, vol. 8, nr. 3, p. 277-281.

Armaş, I. and Gavriş, A. (2013), "Social vulnerability assessment using spatial multi-criteria analysis (SEVI model) and the Social Vulnerability Index (SoVI model) - a case study for Bucharest, Romania", Natural Hazards and Earth System Sciences, vol. 13, no. 6, p. 1481-1499.

Armaş, I., Creţu R.B. and Ionescu R., (2017), "Self-efficacy, stress, and locus of control: The psychology of earthquake risk perception in Bucharest, Romania", International Journal of Disaster Risk Reduction, vol. 22, p. 71-76.

Axxam, S.C.P.A. (2016), "Master plan and development of Bejaia", Urban Planning Direction of Bejaia, Bejaia, p. 7.

Ayadi, K., Boutiba, M., Sabatier, F. and Guettouche, M.S. (2016), 'Detection and analysis of historical variations in the shoreline, using digital aerial photos, satellite images, and topographic surveys DGPS: case of the Bejaia bay (East Algeria)', Arabian Journal of Geosciences, vol. 9, no. 1, p. 1-12. 
Bachari, N.E.I., Houma, F. and Amarouche, K. (2017), "Combination of Satellite Images and Numerical Model for the State Followed the Coast of the Bay of Bejaia-Jijel", International Journal of Environment and Geoinformatic, vol. 4, no. 1, p. 1-7.

Beldjoudi, H., Guemache, M.A., Kherroubi, A., Semmane, F., Yelles-Chaouche, A.K., Djellit, H., Amrani, A. and Haned, A. (2009), "The Lâalam (Béjaïa, North-East Algeria) Moderate Earthquake $(\mathrm{Mw}=5.2)$ on March 20, 2006", Pure and Applied Geophysics, vol. 166, no. 4, p. 623-640.

Bennia, A., Saad, A.Z.E. and Mesbah, C. (2016), "Cartographie de l'aléa géologique au 1/50,000 à partir des images satellitaires à haute résolution (ALSAT-2A) et des systèmes d'information géographique (SIG): cas de la zone pilote de Béjaia", Bulletin des Sciences Géographiques, vol. 19, no. 30, p. 53-59.

Birkmann, J., Garschagen, M. and Setiadi, N. (2014), "New challenges for adaptive urban governance in highly dynamic environments: Revisiting planning systems and tools for adaptive and strategic planning", Urban Climate, vol. 7, no. 1, p. 115-133.

Bo, H. (2015), "Spatiotemporal Characteristics of Rainstorm-Induced Hazards Modified by Urbanization in Beijing", Journal of Applied Meteorology and Climatology, vol. 54, no. 7, p. 1,496-1,509.

Bostenaru-Dan, M. (2006), "Impact of natural hazards on urban areas and infrastructure - Preface", Bulletin of Earthquake Engineering, vol. 4, no. 2, p. 95100.

Boştenaru-Dan, M., Armaş I. and Goretti, A. (2014), "Earthquake Hazard Impact and Urban Planning - An Introduction" in M. Boştenaru-Dan, I. Armaş and A. Goretti (eds), Earthquake Hazard Impact and Urban Planning, Springer Earth Sciences \& Geography - Natural Hazards Series, vol. 1, no. 14.

Bouroumi, M.T., Kacemi, M. and Hamma, W. (2017), "Climate change and their consequences on coastal zone of Ain el Turck in Oran", Urbanism Architecture Constructions, vol. 8, no. 4, p. 355-364.

Capps, K.A., Bentsen, C.N. and Ramírez, A. (2016), "Poverty, urbanization, and environmental degradation: urban streams in the developing world", Freshwater Science, vol. 35, no. 1, p. 429-435.

Castañeda, F.C. (1989), "The risks of environmental degradation in Bogotá, Colombia", Environment and Urbanization, vol. 1, no. 1, p. 16-21.

Chen, K., Zhou, L., Chen, X., Ma, Z., Liu, Y., Huang, L., Bi, J. and Kinney, P.L. (2016), "Urbanization Level and Vulnerability to Heat-Related Mortality in Jiangsu Province, China", Environmental Health Perspectives, vol. 124, no. 12, p. 1863-1869.

Chen, Y., Zhou, H., Zhang, H., Du, G. and Zhou, J. (2015), "Urban flood risk warning under rapid urbanization", Environmental Research, vol. 139, no. 1, p. 3-10.

Cheval, S. (2015), Hazarde naturale în podişul Dobrogei de sud şi litoralul adiacent, Bucharest: Printech.

Demichela, M., Pilone, E. and Camuncoli, G. (2014), "Land use planning around major risk installations: From EC directives to local regulations in Italy", Land Use Policy, vol. 38, no. 1, p. 657-665.

Djouder, F. and Boutiba, M. (2017), "Vulnerability assessment of coastal areas to sea level rise from the physical and socioeconomic parameters: case of the Gulf 
Coast of Bejaia, Algeria", Arabian Journal of Geosciences, vol. 10, no. 14, p. 205223.

Florescu, T. (2009), Formă şi trans-formare urbană, Bucharest: Ion Mincu University Press.

Friend, R., Jarvie, J., Reed, S.O., Sutarto, R., Thinphanga, P. and Toan, V.C. (2014), "Mainstreaming urban climate resilience into policy and planning; reflections from Asia", Urban Climate, vol. 7, no. 1, p. 6-19.

Grecu, F. (2008), Hazarduri şi riscuri naturale geologice şi geomorfologice, Bucharest: Bucharest University Press.

Güneralp, B., Güneralp, I. and Liu, Y. (2015), "Changing global patterns of urban exposure to flood and drought hazards', Global Environmental Change, vol. 31, no. 1, p. 217-225.

Hamma, W. (2018)a, "Forecasting and risk management in Tlemcen: Legislation and urban master plans", Urbanism Architecture Constructions, vol. 9, no. 1, p. 522.

Hamma, W. (2018)b, "The modernization of the port area of Bejaia and its impact on the architectural heritage', Urbanism Architecture Constructions, vol. 9, no. 3, p. 5-20.

Hamma, W. and Petrişor, A.-I. (2017),"Assessing the restoration of Sidi El Benna mosque in Tlemcen (Algeria)", International Journal of Conservation Science, vol. 8, no. 4, p. 589-598.

Hidra, Y. and Kaid Tlilane, N. (2014), "Elaboration d'un modèle prévisionnel pour l'évaluation des couts des accidents de la route a l'horison 2015: Cas De La Wilaya De Bejaïa", Les cahiers du MECAS, vol. 10, p. 126-140.

Highfield, W.E., Peacock, W.G. and Van Zandt, S. (214), 'Mitigation Planning. Why Hazard Exposure, Structural Vulnerability, and Social Vulnerability Matter', Journal of Planning Education and Research, vol. 34, no. 3, p. 287-300.

Hutter, G., Kuhlicke, C., Glade, T. and Felgentreff, C. (2013), "Natural hazards and resilience: exploring institutional and organizational dimensions of social resilience", Natural Hazards, vol. 67, no. 1, p. 1-6.

Jabareen, Y. (2013), 'Planning the resilient city: Concepts and strategies for coping with climate change and environmental risk', Cities, vol. 31, no. 1, p. 220-229.

Knoop, J.M., Bouwman, A. and Visser, H. (2014), 'Sensitivity analyses of the ESPON Climate framework, on the basis of the case study on flooding in the Netherlands', in P. Schmidt-Thomé and S. Greiving, European Climate Vulnerabilities and Adaptation, A Spatial Planning Perspective, Chichester: Wiley Blackwell.

Li, Y., Zhang, X., Zhao, X., Ma, S., Cao, H. and Cao, J. (2016), "Assessing spatial vulnerability from rapid urbanization to inform coastal urban regional planning", Ocean E Coastal Management, vol. 123, no. 1, p. 53-65.

Lillouch, S., Ait Meziane, Y. and Bendadouche, H. (2018), "Geotechnical Cartographic Synthesis of Bejaia City, North East of Algeria", Journal of the Geological Society of India, vol. 91, no. 3, p. 348-354.

Macintosh, A. (2013), "Coastal climate hazards and urban planning: how planning responses can lead to maladaptation", Mitigation and Adaptation Strategies for Global Change, vol. 18, no. 7, p. 1035-1055.

McGranahan, G., Balk, D. and Anderson, B. (2007), 'The rising tide: assessing 
the risks of climate change and human settlements in low elevation coastal zones', Environment and Urbanization, vol. 19, no. 1, p. 17-37.

Mebirouk, H., Boubendir-Mebirouk, F. and Hamma, W. (2018), "Main sources of pollution and its effects on health and the environment in Annaba", Urbanism Architecture Constructions, vol. 9, no. 2, p. 167-182.

Meddour-Sahar, O. and Derridj, A. (2012), "Bilan des feux de forêts en Algérie : analyse spatio-temporelle et cartographie du risque (période 1985-2010)", Science et changements planétaires / Sécheresse, vol. 23, no. 2, p. 133-141.

Moore, M., Gould, P. and Keary, B.S. (2003), "Global urbanization and impact on health", International Journal of Hygiene and Environmental Health, vol. 206, no. 4-5, p. 269-278.

Moulai, R., Doumandji, S. and Sadoul, N. (2008), "Impact des décharges d'ordures ménagères sur le régime alimentaire du goéland Leucophée larus michahellis dans la région de Béjaia (Algérie)", Revue d'Ecologie, vol. 36, no. 3, p. 239-250.

Nassim, H., Laurent, D., Rachid, B. and Djouder, F. (2017), "Instabilités gravitaires dans la région de Béjaiia (Algérie): Inventaire et appréciation de l'importance relative des différents paramètres conduisant au déclenchement, au maintien ou à l'activation des instabilité", Bulletin of Engineering Geology and the Environment, vol. 76, no. 2, p. 1-15.

Nouaceur, Z., Laignel, B. and Turki, I. (2013), "Changements climatiques au Maghreb: vers des conditions plus humides et plus chaudes sur le littoral algérien ?', Physio-Géo, vol. 7, p. 307-323.

Peptenatu, D., Merciu, C., Merciu, G., Drăghici, C. and Cercleux, L.A. (2012), 'Specific Features Of Environment Risk Management In Emerging Territorial Structures", Carpathian Journal of Earth and Environmental Sciences, vol. 7, no. 2, p. 135-143.

Petrişor, A.-I. (2010), "The theory and practice of urban and spatial planning in Romania: Education, laws, actors, procedures, documents, plans, and spatial organization. A multiscale analysis", Serbian Architectural Journal, vol. 2, no. 2, p. 139-154.

Petrişor, A.-I. (2012), "Land cover and land use analysis of urban growth in Romania", Human Geographies - Journal of Studies and Research in Human Geography, vol. 6, no. 1, p. 47-51.

Petrişor, A.-I. (2016), "Geographical Information Systems as Environmental, Landscape, and Urban Planning and Research Tools. Romania as a Case Study" in M. Boştenaru-Dan and C. Crăciun (eds) Space and time visualisation, Geneva: Springer International Publishing, Nature Series, 233-249.

Petrişor, A.-I., Ianoş, I. and Tălângă, C. (2010), 'Land cover and use changes focused on the urbanization processes in Romania', Environmental Engineering and Management Journal, vol. 9, no. 6, p. 765-771.

Qin, H., Romero-Lankao, P., Hardoy, J. and Rosas-Huerta, A. (2015), "Household responses to climate-related hazards in four Latin American cities: A conceptual framework and exploratory analysis", Urban Climate, vol. 14, no. 1, p. 94-110.

Renn, O. and Klinke, A. (2013), "A Framework of Adaptive Risk Governance for Urban Planning", Sustainability, vol. 5, no. 5, p. 2036-2059.

Rivera, C. and Wamsler, C. (2014), "Integrating climate change adaptation, 
disaster risk reduction and urban planning: A review of Nicaraguan policies and regulations", International Journal of Disaster Risk Reduction, vol. 7, no. 1, p. 78-90.

Sharif, H.O., Al-Juaidi, F.H., Al-Othman, A., Al-Dousary, I., Fadda, E., JamalUddeen S. and Elhassan, A. (2016), "Flood hazards in an urbanizing watershed in Riyadh, Saudi Arabia", Geomatics, Natural Hazards and Risk, vol. 7, no. 2, p. 702-720.

Stan, M.I. (2014), "The influence of coastal erosion on the development of southern Romanian Black Sea coastline", Journal of Industrial Design and Engineering Graphics, vol. 9, p. 53-56.

Taşcu-Stavre, M. and Banică, C. (2014), "Old and new in Vama Veche and 2 Mai", Urbanism Architecture Constructions, vol. 5, no. 3, p. 73-82.

Vâlceanu, D.G., Suditu, B. and Petrişor, A.-I. (2015), "Romanian technological risk objectives (SEVESO). Effects on land use and territorial planning", Carpathian Journal of Earth and Environmental Sciences, vol. 10, no. 4, p. 201-208.

Yalaoui-Guellal, D., Brahmi, F., Touati, A., De Champs, C., Banat, I.M. and Madani, K. (2018), "Production of Biosurfactants by Hydrocarbons degrading bacteria isolated from Soummam watershed Sediments of Bejaia in Algeria", Environmental Progress E Sustainable Energy, vol. 37, no. 1, p. 189-195.

Zhai, G., Li, S. and Chen, J. (2015), "Reducing Urban Disaster Risk by Improving Resilience in China from a Planning Perspective", Human and Ecological Risk Assessment: An International Journal, vol. 21, no. 5, p. 1206-1217.

Zheng, Z., Qi, S. and Xu, Y. (2013), "Questionable frequent occurrence of urban flood hazards in modern cities of China", Natural Hazards, vol. 65, no. 1, p. 1009-1010.

Zhou, N.Q. and Zhao, S. (2013), "Urbanization process and induced environmental geological hazards in China", Natural Hazards, vol. 67, no. 2, p. 797 810 .

Zope, P.E., Eldho, T.I. and Jothiprakash, V. (2015), "Impacts of urbanization on flooding of a coastal urban catchment: a case study of Mumbai City, India", Natural Hazards, vol. 75, no. 1, p. 887-908. 